\title{
A Simple Approach to Produce Tailor-Made Chitosans with Specific Degrees of Acetylation and Molecular Weights
}

\author{
Luis-Felipe Sánchez $^{1}\left(\mathbb{D}\right.$, Jimmy Cánepa ${ }^{1}$, Suyeon Kim $^{2}\left(\mathbb{D}\right.$ and Javier Nakamatsu ${ }^{1, *(D)}$ \\ 1 Science Department, Pontificia Universidad Catolica del Peru—PUCP, Av. Universitaria 1801, Lima 32, Peru; \\ lsanchezz@pucp.pe (L.-F.S.); j.canepa@pucp.pe (J.C.) \\ 2 Engineering Department, Pontificia Universidad Catolica del Peru—PUCP, Av. Universitaria 1801, \\ Lima 32, Peru; skim@pucp.pe \\ * Correspondence: javier.nakamatsu@pucp.pe
}

check for updates

Citation: Sánchez, L.-F.; Cánepa, J.; Kim, S.; Nakamatsu, J. A Simple Approach to Produce Tailor-Made Chitosans with Specific Degrees of Acetylation and Molecular Weights Polymers 2021, 13, 2415. https:// doi.org/10.3390/polym13152415

Academic Editor: Luminita Marin

Received: 24 June 2021

Accepted: 15 July 2021

Published: 22 July 2021

Publisher's Note: MDPI stays neutral with regard to jurisdictional claims in published maps and institutional affiliations.

Copyright: (c) 2021 by the authors. Licensee MDPI, Basel, Switzerland. This article is an open access article distributed under the terms and conditions of the Creative Commons Attribution (CC BY) license (https:// creativecommons.org/licenses/by/ $4.0 /)$

\begin{abstract}
Chitin is a structural polysaccharide that is found in crustaceans, insects, fungi and some yeasts. Chitin deacetylation produces chitosan, a well-studied biopolymer with reported chemical and biological properties for diverse potential applications for drug delivery, metal ion absorption, scaffolds and tissue engineering. Most known properties of chitosan have been determined from samples obtained from a variety of sources and in different conditions, this is, from chitosans with a wide range of degrees of $\mathrm{N}$-acetylation (DA) and molecular weight (MW). However, as for any copolymer, the physicochemical and mechanical characteristics of chitosan highly depend on their monomer composition (DA) and chain size (MW). This work presents a simple methodology to produce chitosans with specific and predictive DA and MW. Reaction with acetic anhydride proved to be an efficient method to control the acetylation of chitosan, DAs between $10.6 \%$ and $50.6 \%$ were reproducibly obtained. In addition to this, MWs of chitosan chains were reduced in a controlled manner in two ways, by ultrasound and by acidic hydrolysis at different temperatures, samples with MWs between $130 \mathrm{kDa}$ and $1300 \mathrm{kDa}$ were obtained. DAs were determined by ${ }^{1} \mathrm{H}-\mathrm{NMR}$ and MWs by gel permeation chromatography.
\end{abstract}

Keywords: chitosan; tailor-made polymers; degree of acetylation; molecular weight reduction; biopolymers

\section{Introduction}

Chitin is a structural biopolymer that is found in some marine invertebrates, insects, fungi and yeasts [1], it is a linear homopolymer composed of $\mathrm{N}$-acetylated glucosamine repeat units and it is the second most abundant polysaccharide in nature [2]. Chitosan is produced from the full or partial deacetylation of chitin, it is a linear polymer formed by $(1 \rightarrow 4)$ linked glucosamine and N-acetyl glucosamine units, as shown in Figure 1 [3]. Chitosan is generally soluble in dilute aqueous acidic solutions, which allows it to be purified by $\mathrm{pH}$ changes and to produce a myriad of forms such as gels, films, porous membranes, filaments, pellets and microparticles by evaporation or precipitation techniques [4]. In this regard, chitosan has been extensively studied for its potential in applications like drug delivery [5], water purification and heavy metal absorption [6], materials and coatings with antibacterial activity [7], hydrophilic and porous membranes [8], and scaffolds for tissue engineering [9].

The fundamental parameters that determine the physicochemical properties and behavior of chitosan are the degree of $\mathrm{N}$-acetylation (DA), which reflects the proportion of both repeat units, and the molecular weight (MW). As mentioned before, chitin is obtained from different natural sources, besides washing and sorting out impurities, the extraction of chitin requires, demineralization and deproteinization steps [10,11]. Finally, the conversion of chitin to chitosan, the deacetylation process, usually requires harsh reaction conditions such as a high alkali concentration, high temperatures and long reaction times. A wide range of processing parameters for chitosan production has been reported in the literature, 
each resulting in products with a particular DA and MW, that can differ even from batch to batch [12-15].

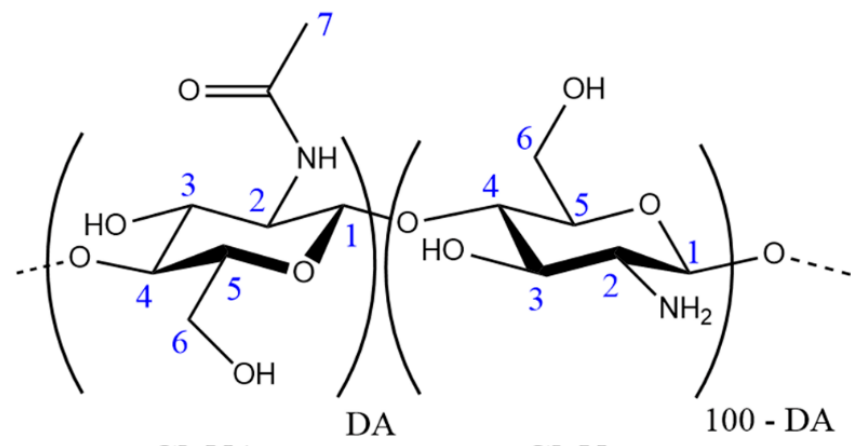

GlcNAc

GlcN

Figure 1. Chitin and chitosan structures showing the acetylated (GlcNAc) and deacetylated (GlcN) units. DA represents the degree of $\mathrm{N}$-acetylation, for chitin $\mathrm{DA}=100$.

As for any polymer, the size of the chains affects the properties and behavior of the material, for instance, its MW may not only affect the mechanical properties and the viscosity of its solutions, but also its solubility, thermal transitions and crystallinity. In the same way, the chemical composition of a copolymer such as chitosan (characterized by its DA) also affects its solubility, crystallinity and thermal behavior, it can even change its affinity to polar or non-polar solvents and its liquid or gas permeability [16,17]. Moreover, it is known that the conformations of chitosan chains depend strongly on the ionic strength of the solvent [18]. Thus, it is important that the DA and MW of every chitosan sample studied are known. Properties of chitosan such as solubility, gas permeability, viscosity and water contact angles on films have been reported showing a whole range of data, which occurs because of the variety of the samples used, with very different MW and DA. This study reports a simple way to produce tailor-made chitosans: polymer chains with a determined MW and DA. Chitosans with a whole range of DAs were selectively obtained by controlled acetylation with acetic anhydride and, the chains were shortened to a particular size either by acidic hydrolysis at different temperatures or by several short exposures to ultrasound radiation.

\section{Materials and Methods}

\subsection{Materials}

Anhydrous acetic acid (HOAc), sodium acetate trihydrate $\left(\mathrm{NaOAc} \cdot 3 \mathrm{H}_{2} \mathrm{O}\right)$, concentrated ammonia, deuterium oxide $(>99.8 \%)$ and deuterium chloride $(>99 \%)$ were purchased from Sigma Aldrich and were of reaction grade. Acetic anhydride $\left(\mathrm{Ac}_{2} \mathrm{O}\right)$, reaction grade, was purchased from Riedel-de-Haën. Pullulan standards (PSS-pulkit, $M_{p} 9.6-2350$ kDa) were purchased from PSS. Milli-Q water was used to prepare the GPC buffer solutions and deionized water was used in the acetylation reactions. Highly deacetylated chitosan flakes (weight-average MW $=1206 \mathrm{kDa}, \mathrm{DA}=10.6 \%$ ), labeled Q10, was obtained from the "Modificación de Materiales" research group at PUCP and chitosan powder (weight-average $\mathrm{MW}=1632 \mathrm{kDa}, \mathrm{DA}=24.3 \%$ ), labeled Q24, was purchased from Sigma Aldrich.

\subsection{Characterization of Chitosan}

The most common methods to determine the degree of acetylation (or deacetylation) of chitosan are IR and ${ }^{1} \mathrm{H}-\mathrm{NMR}$ spectroscopies. The most reliable is ${ }^{1} \mathrm{H}-\mathrm{NMR}$ [19], which can also allow to determine the distribution of the repeat units along the chain [20], however, this method requires that samples be soluble. Solid samples can be characterized by IR spectroscopy, in this case DA determination is a semi-empirical method that compares the relative intensity of different absorption bands. 
2.2.1. Determination of the Degree of N-Acetylation (DA) of Chitosan by ${ }^{1} \mathrm{H}$ NMR Analysis

${ }^{1} \mathrm{H}-\mathrm{NMR}$ spectra were recorded at $70{ }^{\circ} \mathrm{C}$ on a Bruker Ascend (11.75 T) Advance III HD $500 \mathrm{MHz}$ spectrometer equipped with Bruker cryoprobe CP TCI $500 \mathrm{~S} 1 \mathrm{H}-\mathrm{C} / \mathrm{N}-\mathrm{D}-05-\mathrm{Z}$, automatic tunning matching, and autosampler. Chitosan samples were dissolved in a $0.3 \%$ $(v / v)$ solution of $\mathrm{DCl} / \mathrm{D}_{2} \mathrm{O}$ as described in ASTM standard F2260-18 [19]. The DA was determined from Equations (1)-(3)

$$
\begin{aligned}
& {\left[\frac{H_{1} D+H_{2} D}{2}\right]=\text { Deacetylated units proportion }(D)} \\
& {\left[\frac{H_{1} A+\frac{H_{7} A}{3}}{2}\right]=\text { Acetylated units proportion }(A)} \\
& {\left[\frac{A}{D+A}\right] \times 100=\text { Degree of acetylation }(D A)(\%)}
\end{aligned}
$$

where $\mathrm{H}_{1} \mathrm{D}, \mathrm{H}_{2} \mathrm{D}, \mathrm{H}_{1} \mathrm{~A}$ and $\mathrm{H}_{7} \mathrm{~A}$ are the areas of the ${ }^{1} \mathrm{H}$ NMR signals at $4.87 \mathrm{ppm}, 3.20 \mathrm{ppm}$, $4.55 \mathrm{ppm}$ and $2.01 \mathrm{ppm}$, respectively.

\subsubsection{Analysis of the Acetylation Reaction by FT-IR-ATR}

FT-IR-ATR spectra were recorded on a Perkin Elmer Frontier spectrophotometer in the region of $4000-400 \mathrm{~cm}^{-1}$, with 16 scans and a resolution of $4 \mathrm{~cm}^{-1}$. Samples were in powder form and well dried.

\subsubsection{Determination of the Molecular Weight (MW)}

The molecular weights of chitosan samples were determined by gel permeation chromatography (GPC) using a Viscotek system that consisted of a VE7510 GPC degasser, VE1122 solvent delivery system, a VE3580 RI refractive index detector and equipped with a NOVEMA Max analytical linear XL column. Pullulans with $\mathrm{M}_{\mathrm{w}}$ from 10 to $2560 \mathrm{kDa}$ were used as standards for the calibration curve. The software OmniSEC 4.6.2 was used for data processing. The eluent and solvent for chitosan was a buffer solution of $0.2 \mathrm{M}$ $\mathrm{HOAc} / 0.1 \mathrm{M} \mathrm{NaOAc}(\mathrm{pH}=4.5)$, flow rate was set at $0.5 \mathrm{~mL} / \mathrm{min}$ and the column oven temperature at $35^{\circ} \mathrm{C}$. Before injection, samples were filtered with a syringe filter by Millex $(0.45 \mu \mathrm{m})$ as is described by ASTM F2602 methodology [21].

\subsection{Acetylation of Chitosan with Acetic Anhydride}

Chitosan was dissolved in $10 \%(v / v)$ acetic acid to reach a $0.6 \mathrm{~g} / \mathrm{mL}$ concentration. A desired amount of $\mathrm{Ac}_{2} \mathrm{O}$ was added, expressed as a molar relation to glucosamine $(\mathrm{GlcN})$ units in the chitosan sample. The reaction mixture was prepared in a vial at room temperature, with stirring for $5 \mathrm{~h}$. After that time, the solution was dialyzed, with a membrane of pore size 3.5-5 $\mathrm{kDa}$ against deionized water for a couple of days and then the solution inside the membrane was freeze-dried. The re-dissolved sample was treated with $5 \%$ methanolic $\mathrm{KOH}$ at room temperature for $5 \mathrm{~h}$ for O-deacetylation. Finally, the product was washed with methanol and water, and freeze-dried again.

\subsection{Reduction of Chitosan Molecular Weight (MW)}

\subsubsection{Chitosan MW Reduction by Hydrolysis in Aqueous Acidic Media}

Chitosan was dissolved in an aqueous buffer solution of $\mathrm{pH} 4.5(0.2 \mathrm{M} \mathrm{HOAc} / 0.1 \mathrm{M}$ $\mathrm{NaOAc}$ ) to form a $1.5 \mathrm{mg} / \mathrm{mL}$ solution. The solution was divided into three portions that were kept at $4{ }^{\circ} \mathrm{C}, 20^{\circ} \mathrm{C}$ and $50{ }^{\circ} \mathrm{C}$ for 42 days. Aliquots were taken from each portion every seven days and analyzed by GPC for MW determination.

\subsubsection{Chitosan MW Reduction by Ultrasound}

A $2 \%$ chitosan solution $(w / v)$ was prepared as above with the same buffer $(\mathrm{pH}=4.5)$ and chilled in an ice bath to $5{ }^{\circ} \mathrm{C}$. One portion of the solution was exposed for $9 \mathrm{~min}$ to 
ultrasound produced by a Sonics sonifier VCX 750 (frequency of $20 \mathrm{kHz}$ ) with a Cv334 sonotrode (model 630-0219, probe diameter $=13 \mathrm{~mm}$, length $=139 \mathrm{~mm}$, with an amplitude of $40 \%$ ). The probe was immersed in the sample up to $15 \mathrm{~mm}$ from the bottom of the reactor (diameter $=49.2 \mathrm{~mm}$, height $=66 \mathrm{~mm}$ ). The other portion of the chitosan solution was exposed to ultrasound for $3 \mathrm{~min}$, followed by cooling and stirring in an ice bath (for 15 min, until it reached $5^{\circ} \mathrm{C}$ ), the sample was then exposed to ultrasound again for 3 more minutes, cooled down and, finally, it was exposed for 3 more minutes to ultrasound. In this way, both chitosan samples were exposed to ultrasound for a total of $9 \mathrm{~min}$, as the scheme in Figure 2 shows. MWs were determined by GPC.

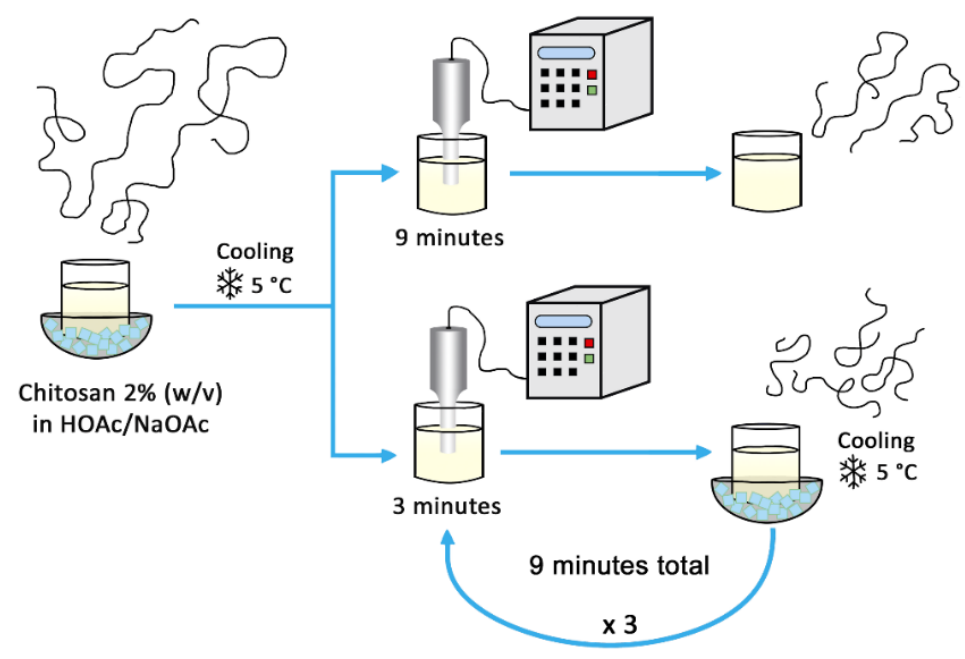

Figure 2. MW reduction with ultrasound.

\section{Results and Discussion}

\subsection{Chitosan Characterization}

The standard test for determining the degree of $\mathrm{N}$-acetylation of chitosan by ${ }^{1} \mathrm{H}-\mathrm{NMR}$ from the ASTM (F2260-18) was used. This method is valid for chitosan soluble samples in the range of DA from 0 to $50 \%$ [19]. Samples were analyzed at $70{ }^{\circ} \mathrm{C}$ to reduce their viscosity and change the chemical shift of the solvent $\left(\mathrm{H}_{2} \mathrm{O}\right)$. The proton assignment can be observed in Table 1.

Due to the solvent's signal overlap with $\mathrm{H} 3$, as can be observed in Figure 3 at $4.28 \mathrm{ppm}$, it was not considered for DA calculation. In this figure, it is easy to see the signal at $4.85 \mathrm{ppm}$, which corresponds to the anomeric proton of the deacetylated units, and the signal at $4.56 \mathrm{ppm}$, that is due to the anomeric proton of the acetylated units. The protons of the carbon next to the amine group in the deacetylated units appear at $3.16 \mathrm{ppm}$ and the signals from 3.56 to $3.87 \mathrm{ppm}$ correspond to the protons in the ring, in both the acetylated and deacetylated units. Finally, the protons of the methyl groups of the acetylated units appear at $2.01 \mathrm{ppm}$ (more protected).

Table 1. ${ }^{1} \mathrm{H}-\mathrm{NMR}$ chemical shifts of chitosan signals.

\begin{tabular}{ccc}
\hline \multirow{2}{*}{ Proton } & \multicolumn{2}{c}{$\delta(\mathbf{p p m})$} \\
\cline { 2 - 2 } & GlcN (D) & GlcNAc (A) \\
\hline H1 & $4.84-4.86$ (doublet) & $4.54-4.58$ (doublet) \\
\hline H2 & $3.15-3.19$ (triplet) & \multirow{2}{*}{$3.56-3.87$ (multiplet) } \\
\hline H3 & $4.22-4.28$ (doublet) & \\
\hline H4-H6 & $3.56-3.87$ (multiplet) & 2.01 (singlet) \\
\hline H7 & - &
\end{tabular}




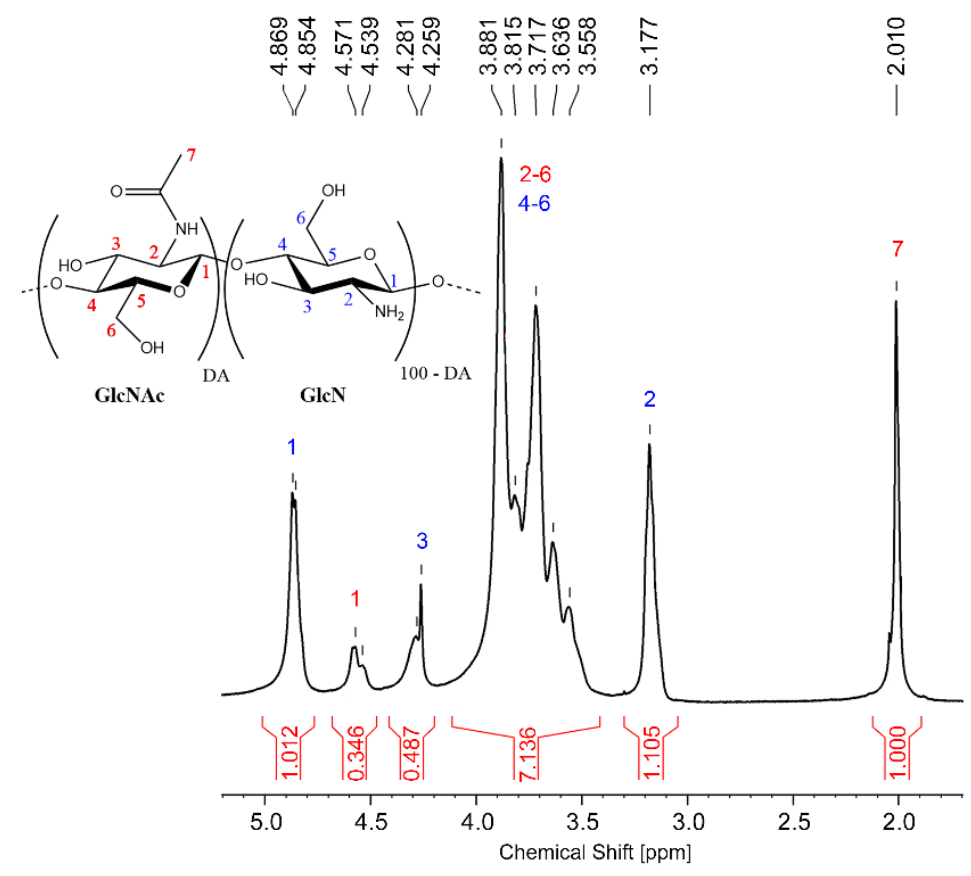

Figure 3. ${ }^{1} \mathrm{H}-\mathrm{NMR}$ spectra of chitosan $\mathrm{Q} 24$ in $\mathrm{DCl} / \mathrm{D}_{2} \mathrm{O}$ at $70{ }^{\circ} \mathrm{C}(500 \mathrm{MHz})$.

The standard test, ASTM F2602-18, for the determination of the MW of chitosan by GPC was used [21]. First, a calibration curve was made with pullulan standards in the range of 10 to $2500 \mathrm{kDa}$ (PSS, Polymer Standard Service). The resulting weight averageMW $\left(\mathrm{M}_{\mathrm{w}}\right)$, number average-MW $\left(\mathrm{M}_{\mathrm{n}}\right)$ and peak-MW $\left(\mathrm{M}_{\mathrm{p}}\right)$ of chitosan Q-24 and Q10 are shown in Table 2. Additionally, shown are the corresponding averages of the degrees of polymerization and the polydispersity indexes for chitosans Q24 and Q10.

Table 2. MWs and DPs of chitosan Q24 and Q10, by GPC.

\begin{tabular}{cccccc}
\hline Chitosan & $\mathbf{M}_{\mathbf{w}} \mathbf{( k D a )}$ & $\mathbf{M}_{\mathbf{n}} \mathbf{( k D a )}$ & $\mathbf{D P}_{\mathbf{n}}$ & $\mathbf{M}_{\mathbf{p}} \mathbf{( k D a )}$ & PDI $^{\mathbf{1}}$ \\
\hline $\mathrm{Q} 24$ & 1632.0 & 233.6 & 1363 & 582.6 & 7.221 \\
$\mathrm{Q} 10$ & 1206.4 & 259.4 & 1566 & 455.7 & 4.667 \\
\hline
\end{tabular}

${ }^{1}$ PDI = Polydispersity index $\left(M_{\mathrm{w}} / \mathrm{M}_{\mathrm{n}}\right)$.

\subsection{Chitosan Acetylation}

Chitosan acetylation has been performed with different reagents, such as acetyl chloride in ionic liquids [22,23]; however, acetic anhydride has been used the most and usually reacted with chitosan in aqueous acetic acid solutions [24-26] (and in mixtures with alcohols and bases [27-34]), at room temperature and for several hours. It has been claimed that the presence of the alcohol in the media aids the reaction of the free amino groups in chitosan with long aliphatic chain anhydrides, and the selectivity of $\mathrm{N}$-acetylation instead of O-acetylation. There is evidence that the reaction of chitosan with acetic anhydride can result in chains with a wide range of DAs, even up to $100 \%$ acetylation, with high reaction yields (85 to $95 \%$ of the recovered mass of the product [31]).

In this work, a homogeneous chitosan acetylation reaction was performed with acetic anhydride in a 10\% $(v / v)$ HOAc aqueous solution. Chitosans with DA of 24.1\% (Q24) and $10.66 \%(\mathrm{Q} 10)$, were reacted with molar ratios of acetic anhydride/glucosamine units $\left(\mathrm{Ac}_{2} \mathrm{O} / \mathrm{GlcN}\right)$ that ranged from 1 to 25 . Only glucosamine units were considered for the ratio calculation since they have the free amino groups that can react with the anhydride. It should be noted that each glucosamine unit can react with up to three acetic anhydride molecules (through one amino and two hydroxyl groups), on the other hand, N-acetylated glucosamine repeat units can react with up to two anhydrides. Taking this into account, a 
chitosan sample with a DA of $\sim 10 \%$ requires an estimated 2.89 moles of acetic anhydride per mole of repeat unit in order to react with all amino and hydroxyl groups in the polymer.

At the reaction conditions used, both the hydroxyl groups and the free amino groups in chitosan react (Figure $4 \mathrm{~A}$ ) and, therefore, the product of esterification and amidation is obtained (Figure $4 \mathrm{~B}$ ) $[35,36]$. The ester groups were then selectively hydrolyzed by alkaline treatment with $5 \% \mathrm{KOH}(w / v)$ methanolic solution $[24,25,37]$. The final product is an $\mathrm{N}$-acetylated chitosan (Figure $4 \mathrm{C}$ ). The reaction yields obtained were above $98 \%$.
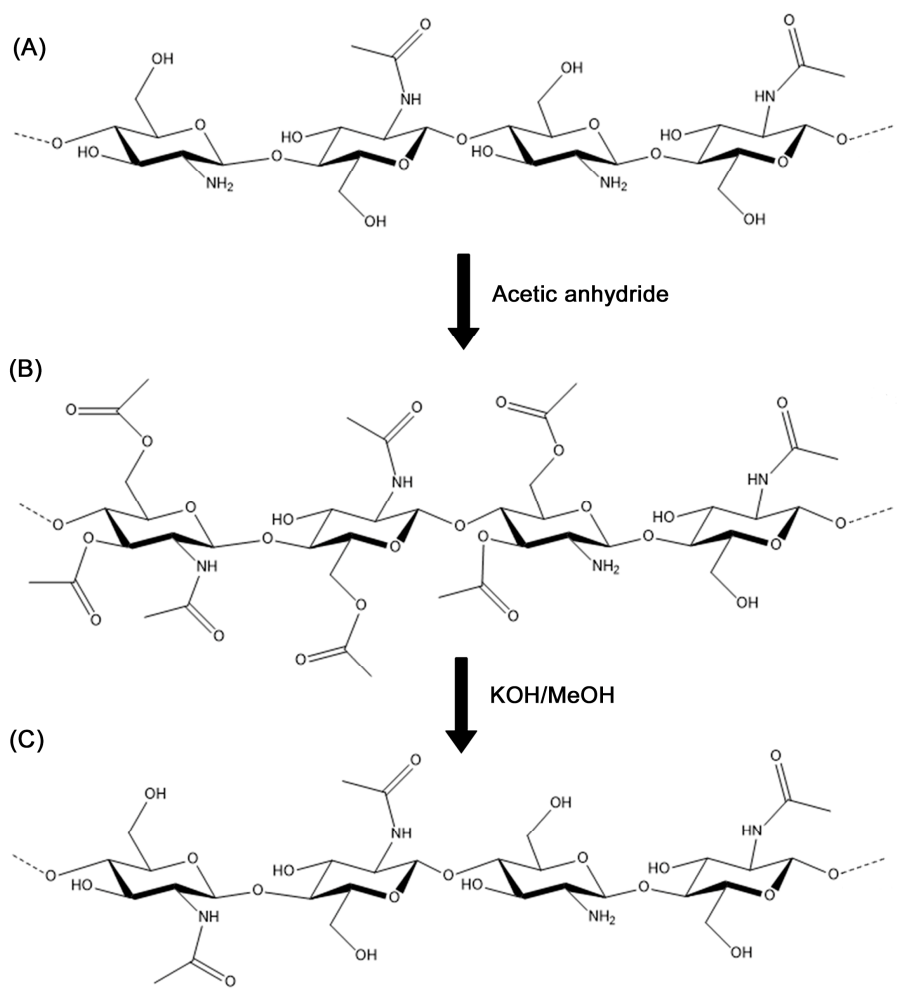

Figure 4. Acetylation reaction showing chitosan (A), O-acetylated and N-acetylated chitosan (B) and $\mathrm{N}$-acetylated chitosan (C).

The reaction pathway shown in Figure 4 was verified qualitatively by IR spectroscopy as is shown in Figure 5. In this figure, FT-IR-ATR spectrum A corresponds to the initial substrate (chitosan Q24) and spectrum B corresponds to the fully acetylated product showing an increase in the intensity of the band at $1655 \mathrm{~cm}^{-1}$ (which corresponds to the vibrations of the $\mathrm{C}=\mathrm{O}$ bond in the amide groups) due to the presence of more $\mathrm{N}$-acetylated glucosamine units [38]. Spectrum B also shows a new band at $1730 \mathrm{~cm}^{-1}$ which is associated with the stretching of the $\mathrm{C}=\mathrm{O}$ bond in esters (produced by $\mathrm{O}$-acetylation). Spectrum C in Figure 5 evidences the selectivity of the hydrolysis of the ester groups with methanolic $\mathrm{KOH}$ by the disappearance of the ester $\mathrm{C}=\mathrm{O}$ band, while the band for the amide $\mathrm{C}=\mathrm{O}$ at $1655 \mathrm{~cm}^{-1}$ remains unchanged. 


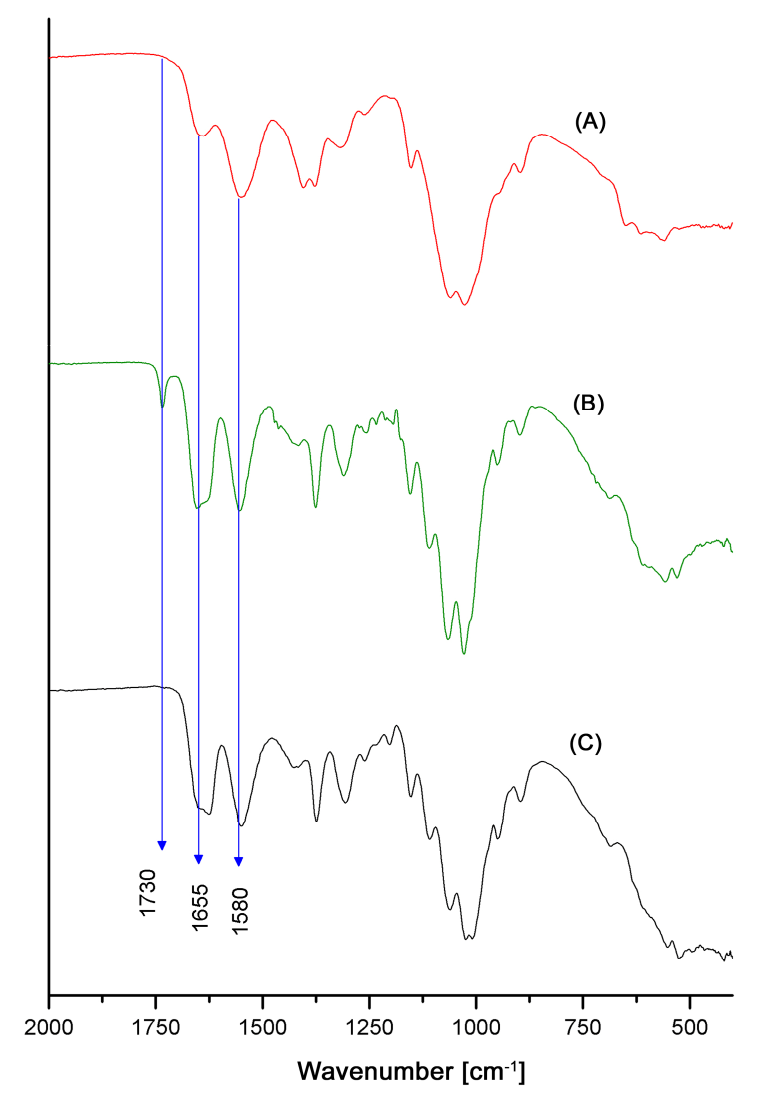

Figure 5. FT-IR-ATR spectra for chitosan Q24 (A), O-acetylated and N-acetylated chitosan (B) and N-acetylated chitosan (C).

Figure 6 shows the ${ }^{1} \mathrm{H}-\mathrm{NMR}$ spectra of the products from the acetylation of Q10 with different ratios of $\mathrm{Ac}_{2} \mathrm{O} / \mathrm{GlcN}$. The peak labeled H1D that appears at $4.85 \mathrm{ppm}$ corresponds to the anomeric hydrogen atom in the deacetylated repeat unit $(\mathrm{GlcN})$, while the signal al $4.55 \mathrm{ppm}$ (labeled H1A) is due to the anomeric hydrogen in the N-acetylated repeat unit. From the spectra shown, it is apparent that the intensities of the peak corresponding to the deacetylated unit (H1D) decrease as the $\mathrm{Ac}_{2} \mathrm{O} / \mathrm{GlcN}$ ratio goes up and, at the same time, the peak of the acetylated unit (H1A) increases in intensity. This shows, as expected, that more $\mathrm{N}$-acetylation occurs when more acetic anhydride is used.

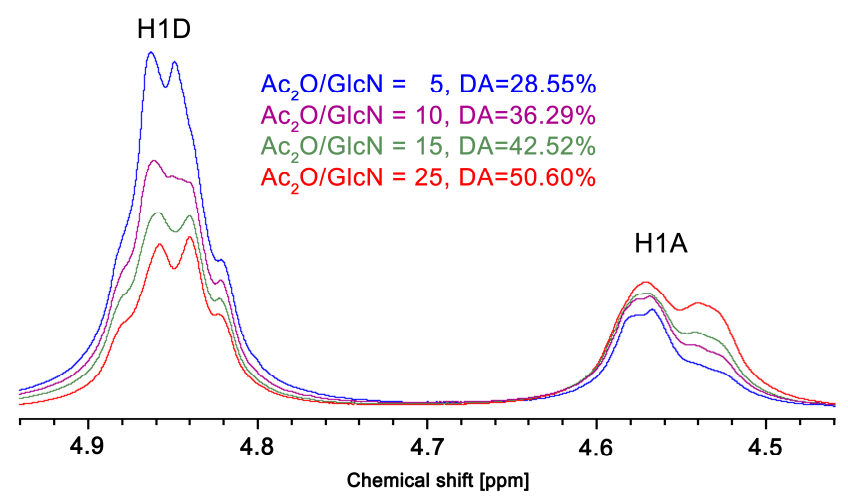

Figure 6. ${ }^{1} \mathrm{H}$-NMR spectra of acetylated chitosans with different $\mathrm{Ac}_{2} \mathrm{O} / \mathrm{GlcN}$ molar ratios $\left(\mathrm{DCl} / \mathrm{D}_{2} \mathrm{O}\right.$, $\left.70{ }^{\circ} \mathrm{C}, 500 \mathrm{MHz}\right)$.

Table 3 shows a summary of the results for the acetylation of chitosan with different $\mathrm{Ac}_{2} \mathrm{O} / \mathrm{GlcN}$ molar ratios. Q10, which is a chitosan with $10 \% \mathrm{DA}$, required an $\mathrm{Ac}_{2} \mathrm{O} / \mathrm{GlcN}$ ratio of around 25 to reach a DA of $50 \%$, while, Q24 (chitosan with $24 \%$ DA) required less 
$\mathrm{Ac}_{2} \mathrm{O}$ to reach the same DA. It is not possible to determine accurately by NMR the DA for highly acetylated products (with DAs higher than 50\%) since they become insoluble in the $\mathrm{DCl} / \mathrm{D}_{2} \mathrm{O}$ solvent system required for $\mathrm{NMR}$ analysis. $\mathrm{Ac}_{2} \mathrm{O} / \mathrm{GlcN}$ ratios higher than those shown in Table 3 produced insoluble chitosans that could not be characterized by ${ }^{1} \mathrm{H}-\mathrm{NMR}$.

Table 3. DA of acetylated chitosans with different $\mathrm{Ac}_{2} \mathrm{O} / \mathrm{GlcN}$ molar ratios.

\begin{tabular}{|c|c|c|}
\hline \multirow{2}{*}{$\mathrm{Ac}_{2} \mathrm{O} / \mathrm{GlcN}$} & Chitosan Q24 & Chitosan Q10 \\
\hline & DA (\%) ${ }^{1}$ & DA (\%) ${ }^{1}$ \\
\hline 0 & $24.31^{2}$ & $10.66^{2}$ \\
\hline 1 & 30.17 & - \\
\hline 2 & 32.71 & - \\
\hline 5 & 37.87 & 28.55 \\
\hline 9 & 43.53 & - \\
\hline 10 & 46.15 & 36.29 \\
\hline 12 & 48.69 & - \\
\hline 14 & $50.47^{3}$ & - \\
\hline 15 & $50.63^{3}$ & 42.52 \\
\hline 20 & - & 46.69 \\
\hline 25 & - & $50.60^{3}$ \\
\hline
\end{tabular}

${ }^{1}$ DA determined by ${ }^{1} \mathrm{H}-\mathrm{RMN},{ }^{2}$ Initial chitosan Q10 and Q24, ${ }^{3}$ Partially insoluble product in acidic media.

Plotted data from Table 3 and an exponential fitting curve are shown in Figure 7. The acetylated products from both chitosans show a similar trend, $\mathrm{N}$-acetylation increases with a higher $\mathrm{Ac}_{2} \mathrm{O} / \mathrm{GlcN}$ molar ratio. Higher ratios resulted in only partially soluble samples, probably due to DA's higher than $50 \%$, and, therefore, could not be determined reliably by NMR spectroscopy in the liquid state. Data in circles correspond to these partially insoluble products, which may show a DA that corresponds only to the soluble part. To test the fitting curve, an acetylation reaction with an $\mathrm{Ac}_{2} \mathrm{O} / \mathrm{GlcN}$ ratio of 7.06 was performed on Q10, the product's experimental DA from NMR resulted to be $33.18 \%$, which is close to $32 \%$, the expected value calculated from the fitting equation. This shows that the fitting could be used as a good reference to produce chitosans with any desired DA, as long as it is below $50 \%[39,40]$.

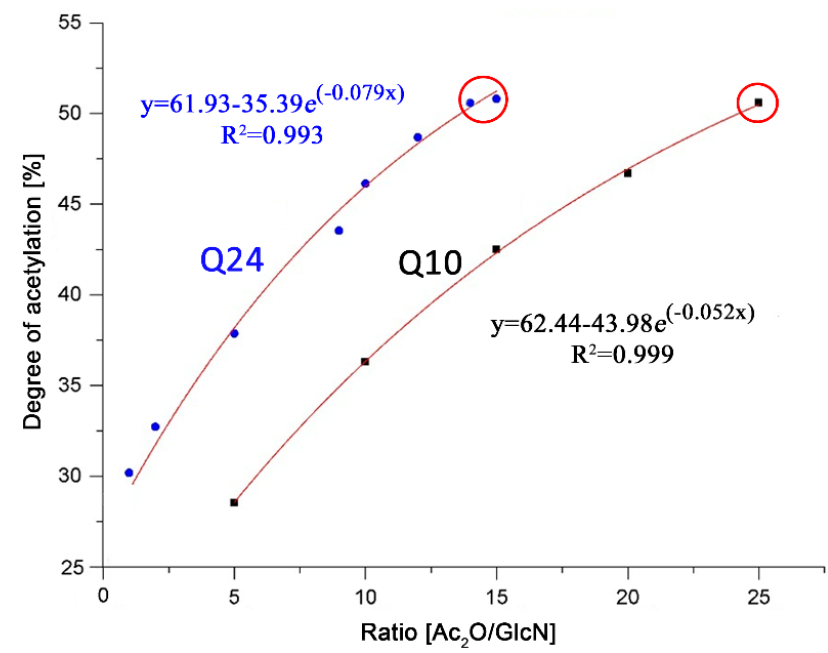

Figure 7. Relationship between the $\mathrm{Ac}_{2} \mathrm{O} / \mathrm{GlcN}$ molar ratio and the DA of the acetylated chitosans Q10 and Q24 (data in circles correspond to partially insoluble products). 


\subsection{Chitosan MW Reduction by Hydrolysis in Aqueous Acidic Media}

The reduction of the molecular weight of chitosan has been reported to occur with aqueous acidic solutions [41], enzymes [42], ultrasound exposure [43-47], nitrous acid [48,49], hydrogen peroxide [50,51] or heating with microwaves [52]. In the case of acidic hydrolysis, two reactions can occur, the cleavage of the main chain by hydrolysis of the glycosidic linkages through an $\mathrm{S}_{\mathrm{N}} 1$ reaction and the hydrolysis of the $\mathrm{N}$-acetyl groups (through an $S_{N} 2$ reaction) [53,54]. It has been reported in the literature that a minimum of deacetylation can also occur during long periods of storage times [55].

If done under control, aqueous acidic conditions can be a readily available and useful method to produce chitosans with shorter chains. For some applications, small chains may be preferred to avoid high solution viscosities, for example $[53,56]$. The shortening of chitosan chains at $\mathrm{pH} 4.5$ was evaluated as a function of temperature and time, and determined by GPC. Figure 8 shows the relative decrease in MW (weight-average molecular weights) of Q24 at $4{ }^{\circ} \mathrm{C}, 20^{\circ} \mathrm{C}$ and $50{ }^{\circ} \mathrm{C}$ during 42 days. It can be observed that, during the first 14 days, the initial MW of $1583 \mathrm{kDa}$ was reduced significantly more at $50{ }^{\circ} \mathrm{C}$ $\left(690.9 \mathrm{kDa}, 56.5 \% \mathrm{MW}\right.$ reduction) than at $20{ }^{\circ} \mathrm{C}(1070 \mathrm{kDa}, 32.6 \% \mathrm{MW}$ reduction) or at $4{ }^{\circ} \mathrm{C}(1203 \mathrm{kDa}, 24.2 \% \mathrm{MW}$ reduction). This is expected since the degradation reaction requires energy to break bonds in the chitosan chains and therefore is more favorable at higher temperatures, similar results have been reported [53]. For the second 14-day period, the MW of the sample kept at $50{ }^{\circ} \mathrm{C}$ decreased in $65.4 \%$ while at $4{ }^{\circ} \mathrm{C}$ the reduction was only $30.3 \%$ of the MW. After 42 days of hydrolysis, the chitosan kept at $50{ }^{\circ} \mathrm{C}$ lost a total of $74.5 \%$ of its size, while at $20{ }^{\circ} \mathrm{C}$ the loss was $48.9 \%$ and $37.1 \%$ for the sample at $4{ }^{\circ} \mathrm{C}$. The yield of acidic hydrolysis was $83.2 \%$. Gordon et al., have reported similar results for the degradation of chitosan after storage for two weeks, 1,3 and 6 months at 4,25 and $40{ }^{\circ} \mathrm{C}$. For six months at $40^{\circ} \mathrm{C}$, they observed a final MW of $64 \mathrm{kDa}$, which corresponded to an $85 \%$ reduction [41].

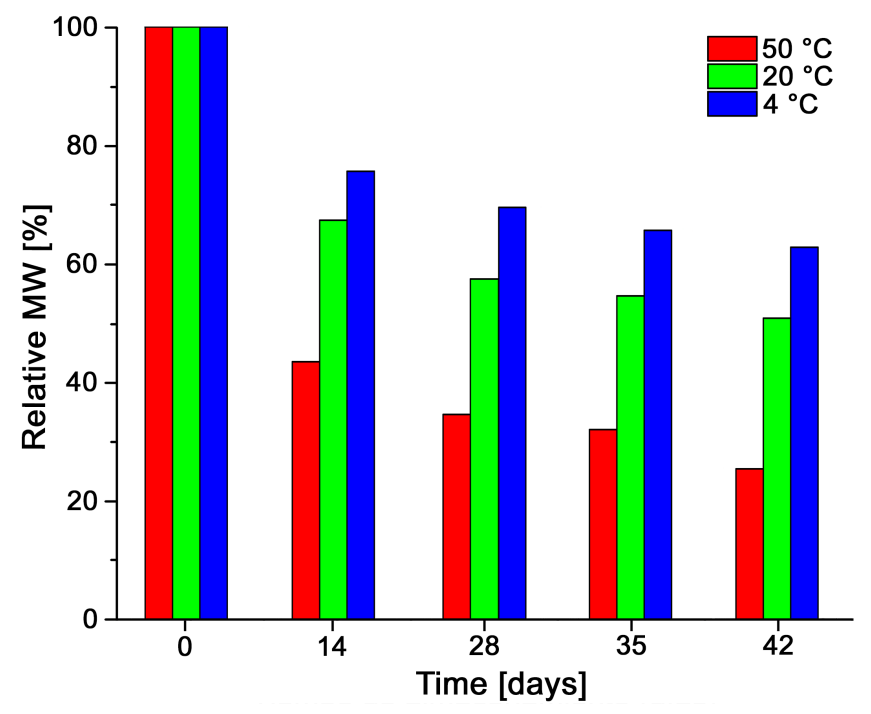

Figure 8. Reduction of the MW of chitosan Q24 at pH 4.5 at 4, 20 and $50{ }^{\circ} \mathrm{C}$.

Figure 9 shows the GPC chromatograms of chitosan Q24 stored at $50{ }^{\circ} \mathrm{C}$ after 14,28 and 35 days, the chromatogram for Q24 is also shown as a reference. A displacement of the retention volumes (from $6.613 \mathrm{~mL}$ to $6.938 \mathrm{~mL}, 7.038 \mathrm{~mL}, 7.108 \mathrm{~mL}$, respectively) can be observed, this evidences a reduction of the hydrodynamic volume of the polymer chains which is related to the decrease of the MW. 


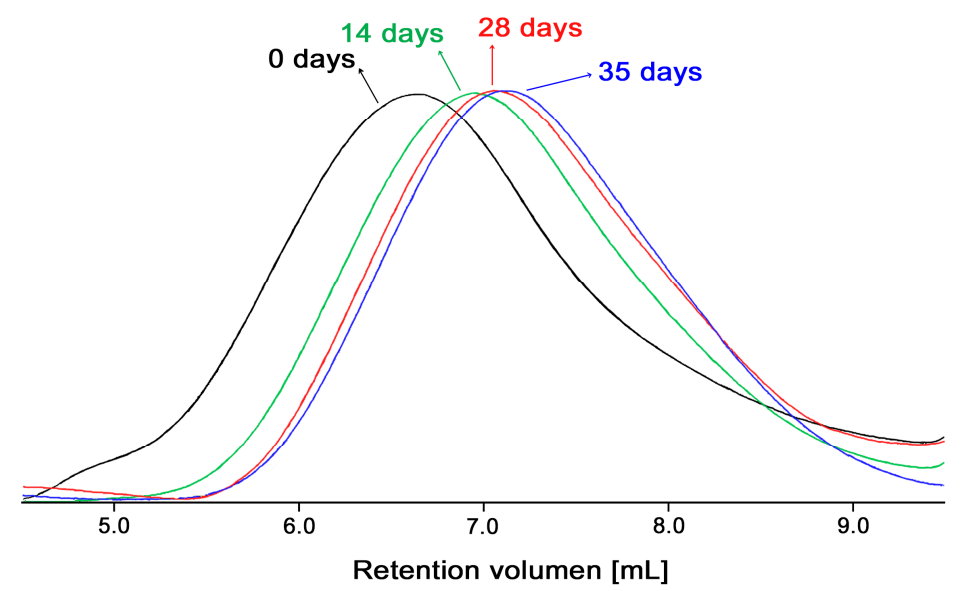

Figure 9. GPC chromatograms of chitosan stored at $50{ }^{\circ} \mathrm{C}$ for $0,14,28$ and 35 days.

\subsection{Chitosan MW Reduction by Ultrasound}

There is a consensus that when exposed to low frequency ultrasound, chain cleavage is mainly due to mechanical forces produced during cavitation $[45,57]$ and it has been reported to be a fast method to reduce its MW $[46,47,58]$. Interestingly, Baxter et al. and $\mathrm{Wu}$ et al. have reported that the degradation by ultrasound does not affect the DA of chitosan when short periods of ultrasound exposure are used $[45,58]$. However, there is evidence in the literature that chitosan can be deacetylated considerably when treated extensively with ultrasound, for a long period of time and in strong alkaline conditions $[59,60]$.

Figure 10 compares the GPC chromatograms for the initial chitosan, chitosan samples treated with ultrasound for one, two and three periods of 3 min each, and also a sample treated continuously for $9 \mathrm{~min}$. The data attached to the figure corresponds to the weightaverage MW obtained from the distribution for each product with the GPC software. The MW of all samples was reduced significantly with ultrasound treatment. As expected, more exposures (of $3 \mathrm{~min}$ each) resulted in lower MWs. However, it is observed that the continuous exposure for $9 \mathrm{~min}$ to ultrasound is less efficient than the three 3-min exposures for reducing the MW of chitosan. In the first case, longer chitosan chains, $858 \mathrm{kDa}$, were obtained, compared to chains of $623 \mathrm{kDa}$, for the second case. This may have to do with different factors, such as the homogenization of the sample by stirring in between the 3-min treatments. Due to the high viscosity of some chitosan solutions, the effect of the ultrasound waves may not be homogeneous across the entire volume of the solution, the portion close to the probe is exposed to a different intensity than a portion of the solution further away. Evidence of this observation is that the GPC chromatogram for the sample that was treated continuously for 9 min shows a greater peak width at half-height $(1.63 \mathrm{~mL})$ and wider PDI (4.3) than the intermittent treatment (three 3-min treatments with cooling and stirring in between), which shows $1.58 \mathrm{~mL}$ half-height width and a PDI of 3.8. Both parameters show that there is a larger variety of chain lengths for the former case. It should be noted that the GPC chromatograms in Figure 10 do not show a bimodal distribution such as Trzcinski et al. observed [46]. These authors explained that a bimodal distribution could be explained by a midpoint chain cleavage model, on the other hand, the random scission of chains model would produce unimodal distribution, as presented by Wu et al. [45]. 


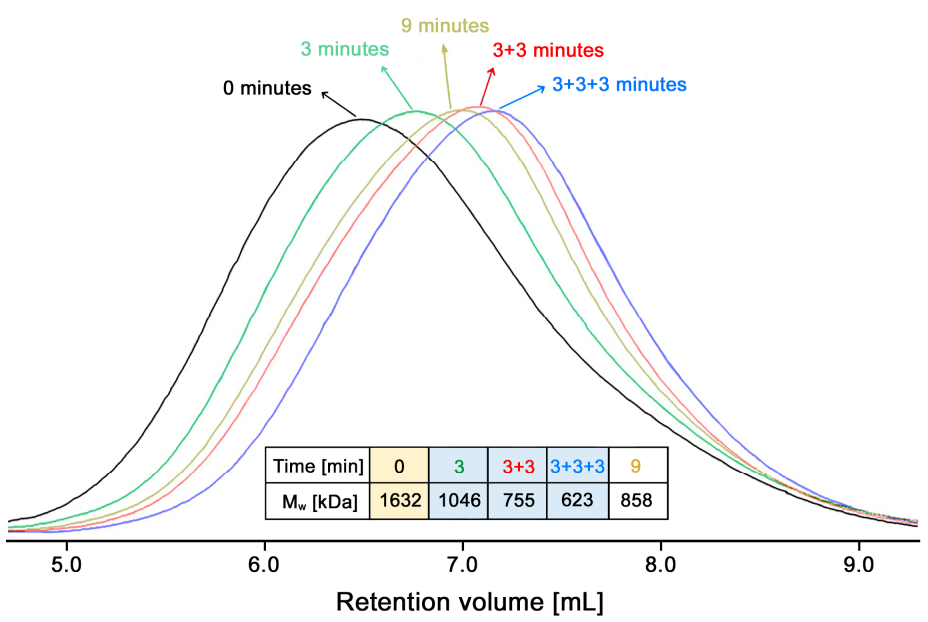

Figure 10. GPC chromatograms of chitosan treated with ultrasound for 9 min straight and for a sequence of three 3-min treatments.

In addition to this, exposure to ultrasound is usually accompanied by heat transfer. It was found that ultrasound could increase the temperature of the sample up to $13.6 \pm 0.9^{\circ} \mathrm{C} / \mathrm{min}$. Taking into account the results reported by Wu et al. [45] showing that chain scission by ultrasound is greater at low temperatures, samples were immersed in an ice bath and stirred after each ultrasound exposure for a more efficient method.

The MW of chitosan samples treated with ultrasound for up to 123 min (forty-one 3-min treatments) is presented in Figure 11. As can be seen, ultrasound treatment applied to a high MW chitosan in solution produced a rapid shortening of the chains and is dependent on the exposure time to ultrasound, as expected. The rate of degradation is high and corresponds to that of a chitosan solution concentration well above the overlap and entanglement concentrations of a high MW chitosan, as explained by Wu et al. [45]. An exponential equation that roughly fits the data can be used to estimate the treatment time needed to produce any desired MW. The lowest MW obtained was $131 \mathrm{kDa}$, a 92\% reduction in MW of the original polymer. Similar graphs have been reported by Popa-Nita et al. and also Wu et al. [45,47], each for different experimental conditions.

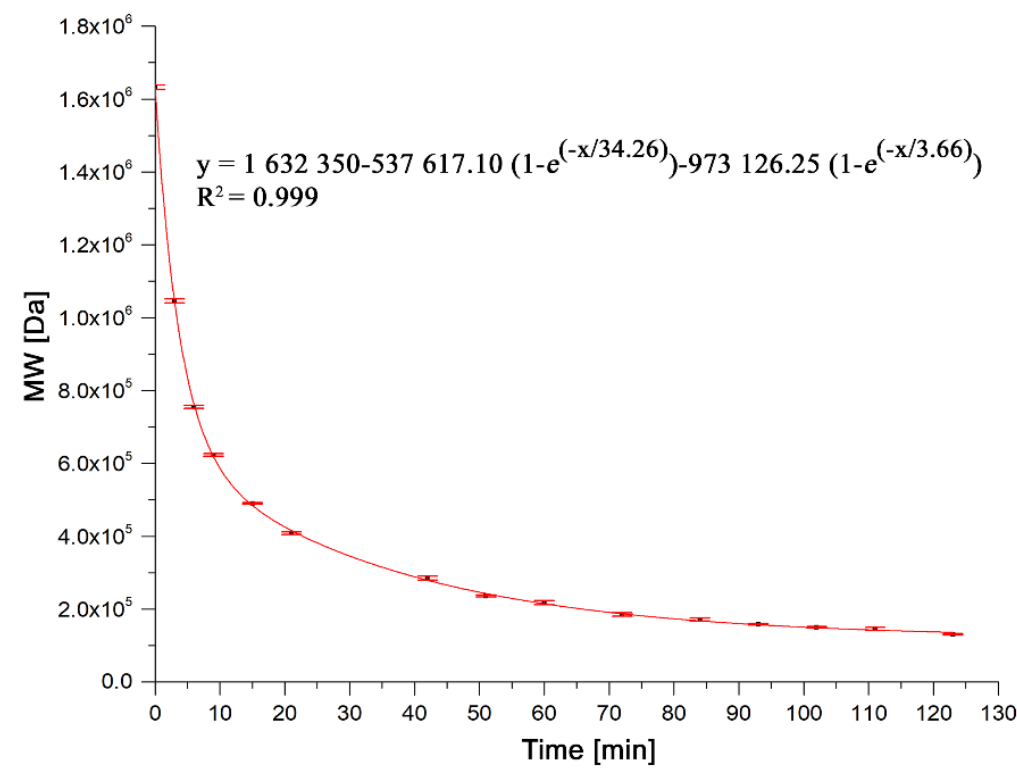

Figure 11. Reduction of chitosan MW with ultrasound $(20 \mathrm{kHz})$ exposure time. 
The results show that ultrasound is a more efficient method to reduce the MW of chitosan than the acidic hydrolysis in terms of time. For example, to reduce the MW of chitosan to $25 \%$ of its original size, hydrolysis for 42 days at $50{ }^{\circ} \mathrm{C}$ is required, compared to $40 \mathrm{~min}$ of ultrasound exposure time.

An advantage of the reduction of the MW with ultrasound is that this procedure does not affect the composition (DA) of the chitosan sample. To test this, a chitosan sample with $\mathrm{DA}=27.46 \%$ that was exposed to ultrasound for three 3-min periods resulted in a product with $\mathrm{DA}=27.26 \%$. Further treatment for three more periods of 3 min each resulted in a chitosan with a DA of $27.62 \%$. No change in DA by ultrasound has also been reported by $\mathrm{Wu}$ et al. [45]. However, Muzzarelli et al. have reported that chitosan deacetylation occurs with long continuous ultrasound exposures (40 $\mathrm{min}$ ) in alkaline media [59].

Finally, as an example of the versatility of the methods studied, Figure 12 shows a scheme in which chitosan Q24 (DA 24.3\%, $1632 \mathrm{kDa}, \mathrm{DP}_{\mathrm{w}}$ 9523) is transformed into three other products, a more acetylated chitosan (DA 46.1\%) with roughly the same $\mathrm{DP}_{\mathrm{w}}$ (9483), a chitosan with the same DA but with lower $\mathrm{MW}\left(\mathrm{DP}_{\mathrm{w}} 5404\right)$ and a chitosan with a higher DA and lower MW and $\mathrm{DP}_{\mathrm{W}}$ (DA $45.7 \%, 765 \mathrm{kDa}, 4242$ ). This simple approach to control the DA and MW of chitosan could serve as a starting point to industrially synthesize tailor-made products and reference materials.

\begin{tabular}{|c|c|c|}
\hline Chitosan Q24 & & Acetylation chitosan \\
\hline $\begin{array}{l}\text { DA: } 24.3 \% \\
M_{w}: 1632 \mathrm{kDa}\end{array}$ & Acetylation reaction & $\begin{array}{l}\text { DA: } 46.1 \% \\
\mathrm{M}_{\mathrm{w}}: 1712 \mathrm{kDa}\end{array}$ \\
\hline $\mathrm{DP}_{\mathrm{w}}: 9523$ & $\mathrm{Ac}_{2} \mathrm{O} / \mathrm{GlcN}=10$ & $\mathrm{DP}_{\mathrm{w}}: 9483$ \\
\hline $\begin{array}{c}\text { Ultrasound } \\
9 \mathrm{~min}\end{array}$ & & $\begin{array}{l}\text { Ultrasound } \\
\quad 9 \text { min }\end{array}$ \\
\hline $\begin{array}{l}\text { Degraded } \\
\text { chitosan }\end{array}$ & & $\begin{array}{c}\text { Acetylated and degraded } \\
\text { chitosan }\end{array}$ \\
\hline DA: $24.4 \%$ & & DA: $45.7 \%$ \\
\hline $\mathrm{M}_{\mathrm{w}}: 926 \mathrm{kDa}$ & & $\mathrm{M}_{\mathrm{w}}: 765 \mathrm{kDa}$ \\
\hline $\mathrm{DP}_{\mathrm{w}}: 5404$ & & $\mathrm{DP}_{\mathrm{w}}: 4242$ \\
\hline
\end{tabular}

Figure 12. Chitosan Q24 acetylation and degradation scheme.

\section{Conclusions}

Many of the applications of chitosan depend on its chemical structure: the degree of $\mathrm{N}$-acetylation and molecular weight. Therefore, it is important not only to fully characterize the samples but to develop methods to synthesize chitosans with any specific DA and MW. In this regard, acetic anhydride can be used as an acetylation agent in a mild, simple and high-yield reaction that can be easily controlled by the molar ratio of the reagent to glucosamine repeat units in the substrate. This acetylation methodology does not affect the size of the chitosan chains. On the other hand, MW reduction can be achieved in two simple ways, by aqueous acidic hydrolysis or by ultrasound. Both depend on the treatment time, the former is simpler and requires no special equipment but the kinetics are slow, the latter is more efficient, and does not change the DA. In this way, tailor-made chitosans, with any desired MW and DA, can be produced from samples with high MW and low DA.

Being able to produce chitosans with specific structures (DA and MW) could aid to interpret contradictory data that can be found in the literature regarding the polymer's properties and characteristics. It may also contribute to the making of chitosan standard samples for easier characterization of this promising biopolymer and to study the behavior of mixtures of chitosans with different DA or MW. 
Author Contributions: Conceptualization, J.N.; investigation, L.-F.S. and J.C.; data curation, L.-F.S. and J.N.; writing — original draft preparation, L.-F.S. and J.N.; writing—review and editing, J.N., S.K. and J.C.; visualization, L.-F.S. and S.K.; project administration and funding acquisition, S.K. and J.N. All authors have read and agreed to the published version of the manuscript.

Funding: The authors gratefully acknowledge the financial support provided through grants DGI2016-1-0052 and DGI-2017-1-0028 from Pontificia Universidad Catolica del Peru (PUCP).

Institutional Review Board Statement: Not applicable.

Informed Consent Statement: Not applicable.

Data Availability Statement: The data presented in this study are available on request from the corresponding author.

Acknowledgments: The Modificacion de Materiales research group at PUCP is gratefully acknowledged for providing the highly deacetylated chitosan and access to the GPC and ultrasound equipment, and the CERMN-PUCP for performing the NMR analysis.

Conflicts of Interest: The authors declare no conflict of interest.

\section{References}

1. Muzzarelli, R.A.A. Enzymatic synthesis of chitin and chitosan. In Chitin, 1st ed.; Pergamon Press Inc.: New York, NY, USA, 1977; pp. 5-44. ISBN 0-08-020367-1.

2. Kaplan, D.L. Polysaccharides: Chitin and chitosan: Chemistry and technology of their use as structural materials. In Macromolecular Systems-Materials Approach, 1st ed.; Christiane Messerschmidt, R., Ed.; Springer: New York, NY, USA, 1998; pp. 96-118. ISBN 978-3-642-08341-9.

3. Campana-Filho, S.P.; De Britto, D.; Curti, E.; Abreu, F.R.; Cardoso, M.B.; Battisti, M.V.; Sim, P.C.; Goy, R.C.; Signini, R.; Lavall, R.L. Extração, estrutura e propriedades de $\alpha$ e $\beta$-quitina. Quim. Nova 2007, 30, 644-650. [CrossRef]

4. Nakamatsu, J.; Torres, F.G.; Troncoso, O.P.; Min-Lin, Y.; Boccaccini, A.R. Processing and characterization of porous structures from chitosan and starch for tissue engineering scaffolds. Biomacromolecules 2006, 7, 3345-3355. [CrossRef]

5. Oh, J.K.; Lee, D.I.; Park, J.M. Biopolymer-based microgels/nanogels for drug delivery applications. Prog. Polym. Sci. 2009, 34, 1261-1282. [CrossRef]

6. Shajahan, A.; Shankar, S.; Sathiyaseelan, A.; Narayan, K.S.; Narayanan, V.; Kaviyarasan, V.; Ignacimuthu, S. Comparative studies of chitosan and its nanoparticles for the adsorption efficiency of various dyes. Int. J. Biol. Macromol. 2017, 104, 1449-1458. [CrossRef]

7. Wu, C.S.; Hsu, Y.C.; Liao, H.T.; Cai, Y.X. Antibacterial activity and in vitro evaluation of the biocompatibility of chitosan-based polysaccharide/polyester membranes. Carbohydr. Polym. 2015, 134, 438-447. [CrossRef] [PubMed]

8. Thakur, V.K.; Thakur, M.K. Recent advances in graft copolymerization and applications of chitosan: A review. ACS Sustain. Chem. Eng. 2014, 2, 2637-2652. [CrossRef]

9. Levengood, S.K.L.; Zhang, M. Chitosan-based scaffolds for bone tissue engineering. J. Mater. Chem. B 2014, 2, 3161-3184. [CrossRef] [PubMed]

10. Younes, I.; Rinaudo, M. Chitin and Chitosan Preparation from Marine Sources. Structure, Properties and Applications. Mar. Drugs 2015, 13, 1133-1174. [CrossRef] [PubMed]

11. Percot, A.; Viton, C.; Domard, A. Characterization of Shrimp Shell Deproteinization. Biomacromolecules 2003, 4, 1380-1385. [CrossRef]

12. Zhao, Y.; Park, R.D.; Muzzarelli, R.A.A. Chitin deacetylases: Properties and applications. Mar. Drugs 2010, 8, 24-46. [CrossRef]

13. Anwar, M.; Anggraeni, A.S.; Amin, M.H.A. Comparison of green method for chitin deacetylation. AIP Conf. Proc. 2017, 1823, 20071. [CrossRef]

14. Nemtsev, S.V.; Gamzazade, A.I.; Rogozhin, S.V.; Bykova, V.M.; Bykov, V.P. Deacetylation of chitin under homogeneous conditions. Appl. Biochem. Microbiol. 2002, 38, 521-526. [CrossRef]

15. Pires, C.T.; Vilela, J.A.P.; Airoldi, C. The Effect of Chitin Alkaline Deacetylation at Different Condition on Particle Properties. Procedia Chem. 2014, 9, 220-225. [CrossRef]

16. Nunthanid, J.; Puttipipatkhachorn, S.; Yamamoto, K.; Peck, G.E. Physical Properties and Molecular Behavior of Chitosan Films. Drug Dev. Ind. Pharm. 2001, 27, 143-157. [CrossRef] [PubMed]

17. Rong Huei, C. Effect of molecular weight of chitosan with the same degree of deacetylation on the thermal, mechanical, and permeability properties of the prepared membrane. Carbohydr. Polym. 1996, 29, 353-358. [CrossRef]

18. Errington, N.; Harding, S.; Vårum, K.M.; Illum, L. Hydrodynamic characterization of chitosans varying in degree of acetylation. Int. J. Biol. Macromol. 1993, 15, 113-117. [CrossRef]

19. American Society for Testing and Materials (ASTM). ASTM F2260-18 Standard Test Method for Determining Degree of Deacetylation in Chitosan Salts by Proton Nuclear Magnetic Resonance (1H NMR); ASTM: West Conshohocken, PA, USA, 2018. [CrossRef] 
20. Lopez, J.M.; Sánchez, L.F.; Nakamatsu, J.; Maruenda, H. Study of the Acetylation Pattern of Chitosan by Pure Shift NMR. Anal. Chem. 2020, 92, 12250-12256. [CrossRef]

21. American Society for Testing and Materials (ASTM). ASTM F2602-18 Standard Test Method for Determining the Molar Mass of Chitosan and Chitosan Salts by Size Exclusion Chromatography with Multi-Angle Light Scattering Detection (SEC-MALS); ASTM: West Conshohocken, PA, USA, 2018. [CrossRef]

22. Liu, L.; Zhou, S.; Wang, B.; Xu, F.; Sun, R. Homogeneous acetylation of chitosan in ionic liquids. J. Appl. Polym. Sci. 2013, 129, 28-35. [CrossRef]

23. Silva, S.S.; Mano, J.F.; Reis, R.L. Ionic liquids in the processing and chemical modification of chitin and chitosan for biomedical applications. Green Chem. 2017, 19, 1208-1220. [CrossRef]

24. Hirano, S.; Ohe, Y. A facile N-acylation of chitosan with carboxylic anhydrides in acidic solutions. Carbohydr. Res. 1975, 41, C1-C2. [CrossRef]

25. Hirano, S.; Ohe, Y. Chitosan Gels-Novel Molecular Aggregation of Chitosan in Acidic Solutions on A Facile Acylation. Agric. Biol. Chem. 1975, 39, 1337-1338. [CrossRef]

26. Kubota, N.; Eguchi, Y. Facile Preparation of Water-Soluble N-Acetylated Chitosan and Molecular Weight Dependence of Its Water-Solubility. Polym. J. 1997, 29, 123-127. [CrossRef]

27. Aiba, S. Studies on chitosan: 1. Determination of the degree of N-acetylation of chitosan by ultraviolet spectrophotometry and gel permeation chromatography. Int. J. Biol. Macromol. 1986, 8, 173-176. [CrossRef]

28. Hirano, S.; Tsuchida, H.; Nagao, N. N-acetylation in chitosan and the rate of its enzymic hydrolysis. Biomaterials 1989, 10, 574-576. [CrossRef]

29. Hirano, S.; Ohe, Y.; Ono, H. Selective N-acylation of chitosan. Carbohydr. Res. 1976, 47, 315-320. [CrossRef]

30. Roberts, G.A.F.; Wood, F.A. A study of the influence of structure on the effectiveness of chitosan as an anti-felting treatment for wool. J. Biotechnol. 2001, 89, 297-304. [CrossRef]

31. Sorlier, P.; Denuzière, A.; Viton, C.; Domard, A. Relation between the degree of acetylation and the electrostatic properties of chitin and chitosan. Biomacromolecules 2001, 2, 765-772. [CrossRef] [PubMed]

32. Sorlier, P.; Viton, C.; Domard, A. Relation between solution properties and degree of acetylation of chitosan: Role of aging. Biomacromolecules 2002, 3, 1336-1342. [CrossRef] [PubMed]

33. Kurita, K.; Koyama, Y.; Nishimura, S.; Kamiya, M. Facile Preparation of Water-Soluble Chitin from Chitosan. Chem. Lett. 1989, 18, 1597-1598. [CrossRef]

34. Kurita, K.; Chikaoka, S.; Kamiya, M.; Koyama, Y. Studies on chitin. 14. N-acetylation behavior of chitosan with acetyl chloride and acetic anhydride in a highly swelled state. Bull. Chem. Soc. Jpn. 1988, 61, 927-930. [CrossRef]

35. Kurita, K. Chitin and Chitosan: Functional Biopolymers from Marine Crustaceans. Mar. Biotechnol. 2006, 8, 203-226. [CrossRef]

36. Hirano, S.; Yamaguchi, R. N-acetylchitosan gel: A polyhydrate of chitin. Biopolymers 1976, 15, 1685-1691. [CrossRef]

37. Sashiwa, H.; Kawasaki, N.; Nakayama, A.; Muraki, E.; Yamamoto, N.; Aiba, S.I. Chemical modification of chitosan. 14:1 synthesis of water-soluble chitosan derivatives by simple acetylation. Biomacromolecules 2002, 3, 1126-1128. [CrossRef] [PubMed]

38. Kumirska, J.; Czerwicka, M.; Kaczyński, Z.; Bychowska, A.; Brzozowski, K.; Thöming, J.; Stepnowski, P. Application of Spectroscopic Methods for Structural Analysis of Chitin and Chitosan. Mar. Drugs 2010, 8, 1567-1636. [CrossRef] [PubMed]

39. Hirano, S.; Yamaguchi, Y.; Kamiya, M. Water-Soluble N-(n-Fatty acyl)chitosans. Macromol. Biosci. 2003, 3, 629-631. [CrossRef]

40. Kurita, K.; Sannan, T.; Iwakura, Y. Studies on chitin, 2. Effect of deacetylation on solubility. Die Makromol. Chem. Macromocular Chem. Phys. 1976, 117, 3589-3600. [CrossRef]

41. Morris, G.A.; Castile, J.; Smith, A.; Adams, G.G.; Harding, S.E. Macromolecular conformation of chitosan in dilute solution: A new global hydrodynamic approach. Carbohydr. Polym. 2009, 76, 616-621. [CrossRef]

42. El-Sayed, S.T.; Omar, N.I.; El-Sayed, E.S.M.; Shousha, W.G. Evaluation Antioxidant and cytotoxic activities of novel chitooligosaccharides prepared from chitosan via enzymatic hydrolysis and ultrafiltration. J. Appl. Pharm. Sci. 2017, 7, 50-55. [CrossRef]

43. Chen, R.H.; Chang, J.R.; Shyur, J.S. Effects of ultrasonic conditions and storage in acidic solutions on changes in molecular weight and polydispersity of treated chitosan. Carbohydr. Res. 1997, 299, 287-294. [CrossRef]

44. Czechowska-Biskup, R.; Rokita, B.; Lotfy, S.; Ulanski, P.; Rosiak, J.M. Degradation of chitosan and starch by 360-kHz ultrasound. Carbohydr. Polym. 2005, 60, 175-184. [CrossRef]

45. Wu, T.; Zivanovic, S.; Hayes, D.G.; Weiss, J. Efficient Reduction of Chitosan Molecular Weight by High-Intensity Ultrasound: Underlying Mechanism and Effect of Process Parameters. J. Agric. Food Chem. 2008, 56, 5112-5119. [CrossRef] [PubMed]

46. Trzciński, S.; Staszewska, D.U. Kinetics of ultrasonic degradation and polymerisation degree distribution of sonochemically degraded chitosans. Carbohydr. Polym. 2004, 56, 489-498. [CrossRef]

47. Popa-Nita, S.; Lucas, J.-M.; Ladavière, C.; David, L.; Domard, A. Mechanisms Involved During the Ultrasonically Induced Depolymerization of Chitosan: Characterization and Control. Biomacromolecules 2009, 10, 1203-1211. [CrossRef] [PubMed]

48. Allan, G.G.; Peyron, M. Molecular weight manipulation of chitosan I: Kinetics of depolymerization by nitrous acid. Carbohydr. Res. 1995, 277, 257-272. [CrossRef]

49. Chattopadhyay, D.P.; Inamdar, M.S. Aqueous behaviour of chitosan. Int. J. Polym. Sci. 2010, 2010. [CrossRef]

50. Tian, F.; Liu, Y.; Hu, K.; Zhao, B. The depolymerization mechanism of chitosan by hydrogen peroxide. J. Mater. Sci. 2003, 38, 4709-4712. [CrossRef] 
51. Xia, Z.; Wu, S.; Chen, J. Preparation of water soluble chitosan by hydrolysis using hydrogen peroxide. Int. J. Biol. Macromol. 2013, 59, 242-245. [CrossRef] [PubMed]

52. Xing, R.; Liu, S.; Yu, H.; Guo, Z.; Wang, P.; Li, C.; Li, Z.; Li, P. Salt-assisted acid hydrolysis of chitosan to oligomers under microwave irradiation. Carbohydr. Res. 2005, 340, 2150-2153. [CrossRef]

53. Kasaai, M.R.; Arul, J.; Charlet, G. Fragmentation of Chitosan by Acids. Sci. World J. 2013, 2013, 1-11. [CrossRef]

54. Einbu, A.; Grasdalen, H.; Vårum, K.M. Kinetics of hydrolysis of chitin/chitosan oligomers in concentrated hydrochloric acid. Carbohydr. Res. 2007, 342, 1055-1062. [CrossRef] [PubMed]

55. Einbu, A.; Vårum, K.M. Depolymerization and De-N-acetylation of Chitin Oligomers in Hydrochloric Acid. Biomacromolecules 2007, 8, 309-314. [CrossRef]

56. Castillo, L.A.; Farenzena, S.; Pintos, E.; Rodríguez, M.S.; Villar, M.A.; García, M.A.; López, O.V. Active films based on thermoplastic corn starch and chitosan oligomer for food packaging applications. Food Packag. Shelf Life 2017, 14, 128-136. [CrossRef]

57. Tsaih, M.L.; Chen, R.H. Effect of Degree of Deacetylation of Chitosan on the Kinetics of Ultrasonic Degradation of Chitosan. J. Appl. Polym. Sci. 2003, 90, 3526-3531. [CrossRef]

58. Baxter, S.; Zivanovic, S.; Weiss, J. Molecular weight and degree of acetylation of high-intensity ultrasonicated chitosan. Food Hydrocoll. 2005, 19, 821-830. [CrossRef]

59. Muzzarelli, R.A.A.; Rocchetti, R. Determination of the degree of acetylation of chitosans by first derivative ultraviolet spectrophotometry. Carbohydr. Polym. 1985, 5, 461-472. [CrossRef]

60. Fiamingo, A.; Delezuk, J.A.D.M.; Trombotto, S.; David, L.; Campana-Filho, S.P. Extensively deacetylated high molecular weight chitosan from the multistep ultrasound-assisted deacetylation of beta-chitin. Ultrason. Sonochem. 2016, 32, 79-85. [CrossRef] 